\title{
Language policy, ideological clarification and theory of mind
}

\author{
Nathan John Albury ${ }^{1}$ (D)
}

Received: 13 August 2018 / Accepted: 13 February 2020 / Published online: 28 March 2020

(c) The Author(s) 2020

\begin{abstract}
This interdisciplinary paper shows that investigating community language beliefs, as a pillar of language policy research, can be enriched by the principles of theory of mind. The case study is Malaysia where ethnonationalist law and policy elevates the language and culture of the Muslim Malay majority above those of citizens of Chinese and Indian ethnicity, but where a seismic political shift is underway. The reelection of Dr Mahathir Mohammad as prime minister in May 2018, but now standing for Pakatan Harapan, broke decades of rule by the traditionalist United Malays National Organisation. Promises are being made to bring an end to Malaysia's racebased politics and foster equality. The situation is ripe for producing contentious and politically-embedded talk in the community about Malaysia's linguistic diversity and ethnonationalist language policy. In that context, this paper analyses how youths from different ethnic groups feel about Malaysia's societal multilingualism. However, the innovation is in then soliciting and analysing the hypotheses of these same youths about how their own heritage languages, as well as societal multilingualism and language policy, are perceived by the other ethnic groups. As Malaysia embarks on political change, exploring beliefs in these interethnic multidirectional terms reveals fissures and alignments between beliefs that are articulated by different youths and the beliefs that are attributed to them. This methodological approach can support language policy processes and research by more richly investigating language beliefs and ideological positioning from multidirectional vantage points.
\end{abstract}

Keywords Multilingualism $\cdot$ Malaysia $\cdot$ Ethnic relations $\cdot$ Language beliefs $\cdot$ Theory of mind

Nathan John Albury

n.j.albury@bb.leidenuniv.nl

1 Leiden University, Rapenburg 70, 2311 EZ Leiden, The Netherlands 


\section{Introduction}

Community beliefs about linguistic diversity, and how this ought to be regulated, are intrinsic to language policy in multilingual societies. In the context of minority language revitalisation, Fishman (1990) explained that the language policies of an authority must be informed by what communities themselves want from their sociolinguistic situation, and therefore called for what he terms "ideological clarification" (p. 17). Not clarifying how a community feels risks "disparity" within a polity between policy goals on the one hand and "deeply felt emotions and anxieties on the other" (Dauenhauer and Dauenhauer 1998). Government language policies may therefore have a greater chance of success if they are informed by community ambitions (Lewis 1981). This of course assumes that alignments can and ought to exist between top-down policy and bottom-up demands which is not assured, not the least in less-than-democratic states. The role of grassroots ideology can still be powerful, however. Schiffman (2006) and Spolsky (2004) argue that community beliefs about language can be so strong that they may ultimately regulate linguistic diversity anyway. Whether from a top-down or bottomup view, this warrants a continued commitment to ideological clarification in language policy scholarship, the process of which is "extremely complicated and involves addressing attitudes and feelings on many levels" (King 2000).

This article sees one of these levels as not only how people feel about diversity and language policy, but also what people claim to be the beliefs of others about that diversity. Theory of mind (see for example Sodian and Kristen 2010) tells us this is worthwhile to investigate because humans, as social actors, act upon a capacity to not only formulate and express their own knowledge and beliefs, but to also attribute mental states and hypothesise the perspectives of others. The social nature of linguistic diversity, the sociopolitical discourses this can inspire, and indeed lived experiences of language policy, make it feasible that people bring those attributions to their discourses and ideas. This warrants research under the banner of ideological clarification because the complexity of social psychology and language discourses means what people claim others feel about diversity and their own languages, and how they are in fact perceived, may not necessarily align and could instead host tensions, misunderstandings, or overestimations.

This paper therefore analyses alignments and fissures between how youths from the Chinese, Indian and Malay ethnic groups in Malaysia feel about societal multilingualism and national language policy, and how others hypothesise they feel. To do this, the paper draws on the social and discursive aspects of theory of mind to examine how these youths constructed and attributed mental states about societal multilingualism to the other ethnic groups. The paper ultimately shows that a multidirectional approach to researching beliefs can augment our understandings of how the sociolinguistic milieu is perceived and how people position themselves within it. Empirically, Malaysia as a test case is timely because a seismic shift is (seemingly) taking place in local politics. The re-election of Dr Mahathir Mohammed, with the support of local Chinese and Indians, has ended 61 years of Malay-centric rule by the United Malays National Organisation 
(UMNO). UMNO had codified ethnocracy in favour of ethnic Malays to affirm that Malaysia is Tanah Melayu (Malay land), Muslim, and Malay-speaking (Andaya and Andaya 2016). Addressing the inequalities entrenched in Malay ethnonationalism may not be out of the question in this new political milieu. A multidirectional investigation of Malaysian perspectives on societal multilingualism therefore not only advances a theoretical union between theory of mind and language policy, but also contributes to discourses about reimagining Malaysian language policy through richly nuanced bottom-up perspectives.

\section{Multilingualism and language policy}

In Malaysia, discourses about societal multilingualism are intertwined, or even synonymous, with ethnic diversity contextualised by migration, post-colonial nationbuilding, economy and religion. Malaysia is around 67\% Malay and other Bumiputra (sons of the soil, indigenous to Malaysia), 25\% Chinese, and $6.8 \%$ Indian (Department of Statistics Malaysia 2015). Malaya, as it was known, was a British colony notionally from 1771 until independence in 1957. British rule saw waves of migration from southern India and southern China. Labour was in short supply for the rubber plantations and the export sector, and the British saw the Chinese and Indians as suitable to fill these gaps with the racialised belief that ethnic Malays were too lazy to work, Indians were accustomed to colonial rule, and the Chinese were entrepreneurial (Andaya and Andaya 2016). The British largely segregated the ethnicities along socioeconomic lines, meaning interethnic networking was not extensive. The Malays remained mostly in rural areas and suffered relative impoverishment, the Chinese dominated business relying on their proficiency in English, and the Indians were mostly confined to the plantations.

The Malay ethnonationalism that informed Malaysia's move to independence in 1957 would also inform language policy. The ideology of Tanah Melayu, to which the Bumiputra are indigenous, meant Malay language, religion and culture will exclusively define Malaysia. Accordingly, Malay became the only official language. Ethnonationalists have continued to position the Chinese and Indians-who had negotiated their citizenship and right to remain-as pendatang (visitors) such that they are tolerated but not legitimised. Malaysia reluctantly agreed to maintain a colonial policy of Mandarin and Tamil-medium primary education, with the requirement that secondary education would be Malay-medium. This would uphold "regard to the intention of making Malay the national language of the country" (Tan 2008). This policy remains in force. Admission to a public Malaysian university requires students, regardless of their linguistic background, to have attended Malay-medium education and to have passed a Malay proficiency test. Those who opt for private secondary education, such as in Mandarin, are disqualified from the public tertiary education system.

Elevating the Malay language helped to construct Malay ethnocracy. Malaysia is not unique in this sense, as linguistic ethnocracy-in situations of intense cultural and linguistic diversity-has examples elsewhere in the region. Hong Kong has elevated Cantonese to the exclusion of educational language rights for Hong 
Kong's historic South Asian minorities (Erni and Leung 2014). India has elevated Hindi-native to some northern areas of India—as the national language one step above regional languages (Mahboob and Jain 2016). Neighbouring Singapore, on the other hand, opted to position all local languages as equal and united the nation through English as a perceived ethnically neutral language (Noor and Leong 2013). For Malaysia, however, a key concern was that ethnic Malays were disadvantaged by the Chinese who had urbanised, acquired more advanced English through commercial relations, and had advanced socioeconomically. From the Malay perspective, the Chinese migrants had not only remained but had come to control economic affairs. The economic disparity, the government explained, caused Malaysia's fatal race riots of 1969 (Andaya and Andaya 2016). An outcome was the New Economic Policy to afford ethnic Malays affirmative action, including special quotas to tertiary education and employment. This in effect codified ethnocracy above meritocracy. The government also tightened its Sedition Act to prohibit any speech that brings contempt against the government or Malaysia's sultans, and that questions the status of ethnic Malays, Islam and the Malay language.

Critical perspectives of Malaysian language policy show, however, that policy may have under achieved (Coluzzi 2017). Malay is not necessarily a language of daily communication and Malaysian society is linguistically very diverse. As Gill (2013) explains, "some of the languages widely spoken especially in peninsular Malaysia are Mandarin, Cantonese, Hakka, Teochew, Foochow and Hainanese, spoken by the indigenous Chinese, and Tamil, Telegu, Malayalam, Punjabi, Hindi, and Gujerati, spoken by the indigenous Indians" (pp. 2-3). By codifying Malay as the sole national language, Malaysia had sought to eventually devalue English. Success has been limited, given English is now not only the language of the former colonial power, but also the language of Malaysia's international connectivity. English also dominates publicly-funded tertiary education, despite laws that stipulate Malay to be the language of instruction (Gill 2013).

Despite efforts for unity, Malaysia remains fragmented. The Chinese community needed a lingua franca parallel to its many Chinese heritage languages, and the community chose Mandarin rather than Malay (Albury 2017). Tamil is the most commonly spoken language in the Indian community, however, the Indian community sooner experiences shift to English than to Malay (David 2017). Malay ethnonationalist politics are still vigorous and have acquired an Islamic tone that assumes universal moral authority. Islam rather than secular law has increasingly become the primary political and legal framework of Malaysia. This may be a result of rhetoric to appeal to Malay constituencies in the face of corruption that plagued ousted prime minister Najib Razak, ideas of pan-Islamic nationalism, or feelings of displacement during rapid westernisation (Fauzi Abdul Hamid 2007). The point for this paper is that a "nearly complete symbiosis between Malay and Muslim identity" has allowed "religious nationalism to serve as a cipher for ethnonationalism-but a version of ethnonationalism that is much less accommodating of minorities" (Barr and Govindasamy 2010, p. 293) whereby non-Malays have "felt increasingly browbeaten into accepting a subordinate status" (ibid p 297).

This made the re-election of Mahathir Mohammed in May 2018 all the more compelling. Standing for the Pakatan Harapan party, his re-election saw Malaysia's 
first break from rule by the Malay ethnonationalist UMNO. He achieved this with the support of ethnic Chinese and Indian voters, albeit he had formerly suppressed those communities with divisive rhetoric (Mahathir 1970). Time will tell whether the new political milieu will transform traditional tensions. On paper, Mahathir promises to reinstate meritocracy, promote neighbourliness between the ethnicities, and even stop silencing dissent against the elevated status of the Malays. Although language policy does not feature explicitly in Pakatan Harapan's manifesto, changes may be afoot that weaken the monopoly of Malay. The deputy prime minister has defended a recent decision to publish a government statement in Mandarin (Ahmad and Tan 2018) and consideration is being given to recognising the private Chinesemedium secondary school qualification (Tho and Tan 2019). It remains to be seen how much change Mahathir can manage. For many Malaysians, top-down change in language policy may be elusive or amount to lofty promises. Under Malay ethnonationalism, Malaysians became used to an absence of political appetite for the advancement of minority language rights, including under Mahathir (Gill 2013). In any case, this dynamic political situation makes it timely to take the ideological temperature of Malaysians vis-à-vis Malaysia's societal multilingualism as an index of Malaysia's diversity. This allows us to start considering whether any eventual topdown change in favour of minority languages under the new government-that may or may not happen-would be supported by ideologies from the bottom-up.

\section{Theory and method}

Discourses and policies about language do not exist in isolation. In the case of multilingual societies, they are often in dialectic relationship to discourses and policies about ethnicity and ethnic diversity. A central theoretical starting point for any research on language in Malaysia is that ethnic consciousness is pivotal to the Malaysian social structure and that reified notions of language, such as Malay, Chinese, and Tamil, index that ethnic consciousness. This warrants an epistemological research orientation in critical multiculturalism (May and Sleeter 2010) with its concern that ethnicities - and languages in the case of Malaysia — are subject to broader power structures, discourses, and regulation that can foster or resist inequality. What is more, ethnicity is a pertinent theme in social psychology. People hold beliefs, presuppositions, judgements and stereotypes about other ethnic groups, their languages, and their sociolinguistic outlooks (Wigboldus and Douglas 2007) and may bring these to their discourses. This also means linguistic diversity as a topic affiliated with ethnic diversity can become subject to metalinguistic commentary ( $\mathrm{Li}$ and Marshall 2018).

Beliefs about societal multilingualism can also be specifically researched (Gal 2006). Feelings about societal multilingualism, as they were solicited in this research, are deemed attitudes. This follows Eagly and Chaiken (1993) who define attitude as a "psychological tendency that is expressed by evaluating a particular entity with some degree of favor or disfavor" (p. 1) whereby the entity, in this case, is societal multilingualism. By taking a direct approach to a specific topic, and without triangulating data with a broader data set of interactions, texts, and naturally 
occurring data, I do not claim to have confidently and comprehensively identified ideologies as a broader collective consciousness. It is, of course, entirely possible that an attitude expressed in qualitative terms towards societal multilingualismor any other sociolinguistic matter-amounts to the manifestation of a language ideology.

A core contribution of the article is that it is interdisciplinary by drawing on the social and discursive elements of theory of mind to solicit multidirectional perspectives on how different Malaysians claim to feel about linguistic diversity. Theory of mind refers to "the ability to attribute mental states (thoughts, knowledge, beliefs, emotions, desires) to oneself and others. This common-sense mentalism is a powerful tool in our everyday predictions and explanations of human action" (Sodian and Kristen 2010). This ability is theorised as part of child developmental psychology and biology, whereby children develop an awareness of reality, representation and the cognitive processes of others. For the purposes of this article, only the tenets that relate to social research are applied. It was not my ambition to apply theory of mind comprehensively and holistically to benefit language policy discourse research. I use only the core perspective that mental states can be and indeed are attributed to others such that "mental state inferences-judgments about what others think, want, and feel—are central to social life" (Ames 2004). The nature of mental states that might be attributed to others is variable, including attitudes to specific issues, assumptions about ideologies held by another collective, and epistemological biases. This means that, for this paper, participants' views on multilingualism amount to attitudes, but hypothesised mental states may include more. The content of what is attributed may in itself have different origins. For example, attributionslike knowledge more broadly - may be based on idiosyncratic assumptions or understandings, or they may be fuelled by ideological forces, such as collective memories and narratives in Malaysia's different communities, such as about race relations, that have since become constructed truths-informed ideology rather than experienceabout Malaysian life (van Dijk 2003).

In a series of 25 semi-structured group discussions, undergraduate students at five public and five private universities across Malaysia, including Penang, Kuala Lumpur, Bangi, Kota Bahru, Kuala Terengganu, Kuching and Miri, spoke in evaluative and epistemic terms about individual and societal multilingualism in Malaysia. The students were from various majors including Malay literature, forensic science, law, finance, management, English, and accounting. This means the data is limited to the perspectives of tertiary educated youth, rather than of youth or Malaysians more broadly. The distinction between public and private institutions also has bearing on the data. Those who were attending public universities will likely have attended public secondary schools. They will instead have experienced the operations of Malaysian language policy in education, as well as diversity in the classroom, and this no doubt informed their social perspectives. Those who were attending private universities and paying higher tuition, however, likely came from a higher socioeconomic bracket. They had probably attended private English or Chinese-medium high schools, and their experience of language policy will have been limited to their exclusion from public universities or the de facto operation of Malay quotas to university places, even if official quotas were abolished in 2002 (Mukherjee et al. 
2017). Because private secondary schools cater to wealthy Malaysians, and especially the Chinese, these students' experiences of diversity may not be as rich as those of their public school peers. Students were grouped by ethnicity, comprising three to six students per group. Table 1 gives a breakdown of the student groups.

By grouping students, I do not imply that reified ethnicities in Malaysia constitute absolute identities. From a postmodern perspective, essentialising groups of people and their discourses by ethnicity can be problematic. Just as race and ethnicity are social constructs rather than biological facts, Western scholarship tells us it is problematic to associate perceived ethnicity with ideological and cultural affiliations. This liberates individuals from definitive prescriptions and accepts complexity. However, reified notions of ethnicity—and indeed language oftentimes in direct indexical relationship to ethnicity-do nonetheless frame local Malaysian life and policy, and constitute lived local realities for Malaysian youths (Noor and Leong 2013). A responsive methodology must therefore accept that essentialised ethnicity informs how Malaysians structure their sense of self within the broader community (Liu et al. 2002). Secondly, grouping the students by ethnicity circumvented the risk of non-Malays being perceived as inciting racial discord within any views about multilingualism. Grouping students by ethnicity was therefore ethically responsible, but care should be taken not to equate dispositions expressed in ethnically defined groups as more broadly representative. Interviewing in groups also allowed students to participate with their friends who, the students explained, tend to be from the same ethnic group. Youth were the focus of the research because youth can be seen as especially susceptible to, and representative of, acculturation processes (Berry et al. 2006). This is especially pertinent in the case of Malaysia where the youth of today are predicted to be the first leaders of Malaysia as a fully-developed nation, as is the aspiration of the Malaysian government under its Vision 2020.

The discussions were held in English, as I am not proficient in other local languages, and university populations offer participants with sufficient English language proficiency. Naturally, this means the research is limited to youths who are themselves highly multilingual with especially high competence in English, and probably with ideological support for it, and who may have a more critical than average perspective as a result of university education. It is also possible, however, that my position as a non-Malaysian benefitted the research. As a perceived outsider I was seen as free of the shackles of local ethnic politics (Kusow 2003) and therefore an ideal sounding-board for conveying ideas on topics that might otherwise be taboo among Malaysians. Similarly, this also meant the students could not assume that I intersubjectively shared knowledge or assumptions

Table 1 Breakdown of student groups

\begin{tabular}{llll}
\hline & $\begin{array}{l}\text { Number of ethnic Malay } \\
\text { groups }\end{array}$ & $\begin{array}{l}\text { Number of ethnic Chinese } \\
\text { groups }\end{array}$ & $\begin{array}{l}\text { Number of } \\
\text { ethnic Indian } \\
\text { groups }\end{array}$ \\
\hline Public institutions & 6 & 3 & 2 \\
Private institutions & 3 & 7 & 3 \\
\hline
\end{tabular}


with them about language and politics in Malaysia. The students therefore had to explain their ideas and comments in more detailed terms, which in itself created richer data about knowledge and perceptions.

Students were recruited with the assistance of local linguistics departments, in return for a guest lecture. The discussions lasted around $45 \mathrm{~min}$ each and tasked the students to describe and rationalise a range of sociolinguistic phenomena including, inter alia, national language policy, the role of English, and personal language choices. This article analyses responses to two core questions:

1 Students were asked how they feel about Malaysia being a multilingual society. This would solicit attitudinal responses about the desirability of linguistic diversity in contemporary Malaysia, including in the context of Malay nation-building. This question tended to lead to discussions about Malaysia's language policy. However, because questioning the status of Malay can be deemed seditious under Malaysian law, feelings about language policy were never explicitly requested.

2 The students were asked how their languages, and societal multilingualism more broadly, are perceived by the other ethnic groups. This meant hypothesising how their own languages - as indexes of their ethnicity — are constructed and perceived in the minds of others and in respect to the broader ideological environment. This would supplement the data obtained from question one by creating an opportunity to investigate firstly whether expressed and attributed dispositions between groups align or diverge, and secondly where participants feel they are ideologically positioned within the broader sociolinguistic environment.

The data was analysed critically through a discourse-historical lens (Wodak and Meyer 2009). This meant positioning the data vis-à-vis Malaysian historical, ethnic, political, cultural, economic and social contexts that the youths presupposed in their metalinguistic talk-both in their attitudes towards multilingualism and their hypotheses of how the other ethnic groups feel about it. Responses to the two core questions are discussed together by ethnicity. This allows for a multidirectional analysis of each ethnicity's social psychology in terms of their attitudes towards societal multilingualism and the mental states they attributed to others. The number of discreet comments generated by the different ethnicities to the two questions can be seen in Table 2. These were identified, through stance analysis (Jaffe 2009), as linguistic turns that either expressed an attitude towards

Table 2 Number of comments per ethnicity to each question

\begin{tabular}{lcll}
\hline Ethnicity & $\begin{array}{l}\text { Total number focus- } \\
\text { group discussions }\end{array}$ & $\begin{array}{l}\text { Number of attitudinal comments } \\
\text { about societal multilingualism }\end{array}$ & $\begin{array}{l}\text { Number of comments that } \\
\text { attributed mental states to other } \\
\text { ethnicities }\end{array}$ \\
\hline Malay & 9 & 38 & 19 \\
Chinese & 11 & 31 & 28 \\
Indian & 5 & 9 & 17 \\
\hline
\end{tabular}


multilingualism or language policy, and which speculated or claimed knowledge about the beliefs of others about societal multilingualism or language policy.

The unequal number of comments between the ethnicities discourages comparisons. Nonetheless, each group produced multiple comments, and it is striking that relative to their cohort size, ethnic Malays expressed the most attitudes towards societal multilingualism. This suggests they already held specific views and were eager to express them. The table also shows that while Malay youths expressed relatively more attitudes than attributed mental states, the reverse was true for ethnic Indians. As the smallest pendatang minority, the topic of how their languages are perceived in society may already feature in their social psychology or discourses about their language. The article now turns to a content analysis of the qualitative data.

\section{Malay discussions}

This section shows that most Malay participants were enthusiastic about societal multilingualism, rather than sceptical or threatened by it, as dominant Malay discourses and language policy might presuppose. Whereas Malay ideology has traditionally seen non-Malay cultures and languages as a threat to Malay sovereignty (Noor and Leong, 2013), these students tended to see societal multilingualism as uniquely Malaysian and culturally rewarding. They even argued that Malay individuals should rise above the ethnonationalist ideology that has structured Malay politics to instead become multilingual individuals themselves. Acquiring other languages, especially Mandarin, was seen as advancing their social and economic opportunities. In some instances, this enthusiasm presupposed that it is novel, rather than normative, for ethnic Malays to be positive about ethnic and linguistic diversity. Nonetheless, Malays did rearticulate a hierarchy whereby non-Malay languages are welcome, but Malay should retain a higher status on the basis of Tanah Melayu. These students therefore correctly attributed negative affect to Chinese and Indians about this linguistic hierarchy and produced arguments to delegitimise the nonMalay lamentations they had hypothesised.

Malays presented notably positive attitudes to societal multilingualism that welcomed non-Bumiputra languages in all but two of 38 comments, whereby 15 comments endorsed multilingualism as enriching Malaysian society or individuals. For example, six referred to societal multilingualism as necessary for maintaining ethnolinguistic identities, such as in these exchanges: serves multilingualism in Malaysia. If we get rid of Jenis Kebangsaan [Vernacular Schools], it's like, slowly it's going to be like Indonesia. Like, if you are Chinese in Indonesia, you still have an Indonesian name, you have to learn Indonesia Bahasa and you can only practice the language of your mother tongue in your house. That's all. So, our country must work on how to preserve the multilingual, the multicultural, yeah. 


\begin{tabular}{lll}
\hline (2) & Student 4: & It is good actually. \\
& Student 2: & Yeah, it shows our identity. \\
& Student 4: & It shows the Malaysian identity actually. \\
\hline
\end{tabular}

Presupposed within these exchanges, and others like them, is the impetus to stop Malaysia becoming monolingual and monocultural. The first exchange positions Indonesia as an example to be avoided, with the attitude that Chinese Malaysians must be free to exercise Chinese identities, to use their languages in public domains and, arguably, not be compelled to learn Malay. This attitude implies support for linguistic and ethnic plurality. The second exchange builds on this to define linguistic diversity as a Malaysian identity, shared equally by Malays and non-Malays. This contrasts starkly with policy and ethnonationalist discourses that reassert Malaysia as Tanah Melayu whereby non-Malays cannot be considered authentic citizens.

Others, amounting to seven comments, correlated societal multilingualism with individual multilingualism whereby diversity contributes to cultural awareness, intercultural respect, and to cultural "open-mindedness". They argued that "[Malays] want their children to learn more than one language. They also think this could eliminate those misunderstandings and miscommunication between the races", that "it's quite interesting to have many languages in our life because like oh I know something new! Oh its new! It can make life more colourful", and that "actually, being multilingual makes you more open-minded like you are not going to mock another language. Like monolingual people think we are weird if our first language is not English". These comments are enlightening if examined as discourse. Firstly, they presuppose that actually engaging in diversity, rather than living parallel to it, is still very marked in Malaysia. This would explain their emphatic enthusiasm for diversity as a unique opportunity for new knowledge, rather than constructing their engagement in diversity as normative. Secondly, the emphasis on fostering Malay open-mindedness is a criticism of ethnonationalist Malay discourses that encourage Islamisation despite religious diversity, that are sceptical of the Chinese, and that uphold the supremacy of the Malay language despite multilingualism. To these youth, ethnic tensions may be broken down through Malay acceptance of diversity rather than the acculturation of pendatang. Thirdly, they presuppose an epistemology that multilingualism is not exceptional in the human experience.

Another ten comments also departed from discussing societal multilingualism but constructed individual multilingualism as economically and socially enfranchising for Malays. Nonetheless, they maintained that ethnic Malays are disadvantaged in Malaysian society, but this time because Malays are typically bilingual whereas non-Malays are typically multilingual. They noted that "we only know two languages: Malay and English. But for Indians and the Chinese, most of them know three". Others added that learning Mandarin would raise Malay socioeconomic mobility, arguing "we want the Malay people, Malay students, to learn Mandarin. So at least we won't have trouble when we work with a Chinese company. And that way the Chinese boss treats us equally". For these students, it is a fait accompli that Mandarin holds more linguistic capital than Malay. Rather than expressing a preference to inverse this balance, these students felt Malays 
should keep pace and language policy should promote Mandarin. The remainder constructed multilingualism as enhancing social networks. They implied that despite policy, non-Malays are not on a path of language shift to Malay, that nonMalay languages are here to stay, and that embracing diversity enhances Malay life. They explained that current language policy "creates a barrier from a young age between Malays, Chinese, Indians" and

Student 2:

Student 6:

Student 2:

Researcher:

Student 2:
If we learn so many languages, then we can communicate [with each other]. It's beautiful to me.

[But] we just understand a few words only.

Of what they are talking about.

So multilingual is good for...?

Social interaction.

The remaining comments supported societal multilingualism with polarised caveats: either that languages in Malaysia should all be deemed equal in law, or indeed that languages are not equal. To begin, two comments explained that societal multilingualism must be supported because it is morally wrong to suppress non-Malays and non-Malay-medium education. These Malays argued for equality between the ethnicities, with views such as "people should respect their languages" and "just like Malays, the mother tongue of Malays is Malay language, the same goes for them. Tamils, Tamil language is their mother tongue". On the other hand, ten comments that supported societal multilingualism-for whatever reason-also asserted the need for a linguistic hierarchy. They endorsed multilingualism as long as pendatang languages do not achieve equality with the chosen hierarchised language. However, students were not unanimous on what that hierarchised language should be. One group argued this should be Arabic because Malaysia is Islamic and Arabic is the language of Islam. Another two groups argued that it should be English as it serves as an interethnic leveller and logical lingua franca, or English and Malay in tandem. However, the remaining eight comments specifically argued that Malay must remain hierarchised in policy because Malaysia is Tanah Melayu and this promotes interethnic friendships:

Student 1:

Student 2:

Student 1:

Student 2:
Say you are really fluent in Malay and you go buy something in a Malay store that is owned by Malay people...

They will give you everything.

Harga barang ni terlalu mahal. Boleh minta diskaun tak? [The price is too expensive, can you give a discount?]

And then when you finish, they will ask for a selfie.

The notion here is that Chinese and Indian-Malaysians can forge closer relationships with ethnic Malays if they can speak Malay. Although the above excerpt offers a comical-and perhaps exaggerated-illustration, the group sought to express the view that Malays will quickly befriend the others if they speak the national language. 
When asked how the Chinese and Indians feel about Malay-in the context of policy that it is the sole national language-only seven of 19 comments attributed them with positive mental states. Instead, they reproduced a synchronic observation, void of critical nuance, that the Chinese and Indians prize Malay for instrumental purposes. For example, they explained that non-Malays are glad to learn Malay "because it is compulsory at school" and "they can make friends with Malays", rather than hypothesising the effects of policy and ideology. Some explained that non-Malays are enthusiastic about Malay because it is prestigious and because they are excited to interact with Malays. Others explained that nonMalays enjoy learning Malay because it is easier to learn than their own heritage languages. While this does not account for the linguistic, social, or educational challenges of non-Malays who have been socialised in their heritage languages and then acquire Malay, it did form a seemingly apolitical rationale for why nonMalays are, or should be, enthusiastic about Malay. For example:

$\begin{array}{ll}\text { Student 5: } & \text { I think it's ok for them. Bahasa Malaysia is not really hard. } \\ \text { Student 2: } & \text { Yeah, it's a pretty easy language to learn. } \\ \text { Student 3: } & \text { Compared to Tamil and the Chinese, because Chinese has } \\ \text { the characters, not the alphabet, but characters. } & \quad \text { And those who study Chinese have also to learn the tones. }\end{array}$

Another four comments attributed neutral affect, such as that non-Malays view the Malay language as "normal", while another three explicitly explained they do not know how the Chinese and Indians feel. This is not surprising, given the sensitivity of ethnic affairs and the fact that public discussion about ethnic relations is prohibited. Either the students wished not to share their view as the topic was deemed too contentious, or they genuinely have never discussed these issues with non-Malays. To this end, two explained "I'm not really exposed to how the other races think about it", and "it's very sensitive, especially about race and discrimination, so they don't talk about it".

However, the remainder hypothesised that ethnic Chinese and Indians hold negative attitudes towards the Malay language, especially its status. They argued that non-Malays see policy as displacing non-Malay identities and rights in what is meant to be an egalitarian multicultural society. They explained, for example, "it is a hot issue, and they say that if Malay could be the national language, why not their language? Like Tamil and Mandarin, why don't Tamil and Mandarin become the national language as well?", and "some of them think 'why should I learn Malay? It's not like I was born with that language'”. Malay students typically offered counter arguments to delegitimise these hypothesised non-Malay mental states. They argued that it would be easier if non-Malays simply accepted the status quo because "whether they like it or not, if they have to do something with government staff, they still have to speak Malay". They also argued that nonMalays should respect Tanah Melayu and the history of Malay in colonial times: 
(6) Student 3: If you really learn history, then you will know why we actually speak Malay, why Malay is actually our lingua franca. Like, people travelled to Malaysia also at that time. At that time we called it Tanah Melayu, so people travelled here and they also spoke Malay. I think they should accept that Bahasa Malaysia is the national language.

\section{Chinese discussions}

This section shows that the Chinese participants were also enthusiastic about societal multilingualism. Their own attitudes in support of societal multilingualism in Malaysia were mostly premised by the impetus, and their perceived right, to maintain their own ethnic identity in the face of Malay discourses that threaten it. However, when asked how Malays and Indians feel about linguistic diversity, they especially explained that others see Mandarin as enfranchising and intrinsic to the Malaysian economy, meaning it is popular and sometimes seen as more important than Malay. That is to say, their own arguments in favour of multilingualism biased arguments based in ethnicity and culture, whereas their attributed mental states typically biased socioeconomics.

All but one comment about societal multilingualism was positive. The one comment that expressed a negative attitude argued that it is cognitively too demanding to negotiate Malaysia's linguistic diversity. Another four comments argued, in terms similar to those offered by the Malays, that societal multilingualism makes Malaysia culturally unique as a nation, and that it promotes cultural awareness and respect between the ethnicities. They explained, for example, that "it makes a very unique culture compared with other countries", and interestingly,

(7) Student 1: I mean like if you want to compare, [in] Malaysia we have more languages than China or the US, but we don't have the relationship problem between races because we try to accept each other's cultures. But in other countries they reject, that's why they quarrel, fighting. All these things happening. The racist things.

Here, the student may have intentionally avoided discussing ethnic tensions with the understanding that such debate is sensitive. However, the comment may reflect a broader Chinese-Malaysian experience. Because the community holds the balance of wealth, it can often pay to circumvent core language policy domains where Malay hegemony is most pronounced. For example, and as discussed earlier, Chinese students do often attend private education through to the tertiary level. This means they study outside the direct reach of national language policy, and often mostly with other Chinese. Chinese socioeconomic standing also likely leads many to network primarily, for both social and economic reasons, with other Chinese-Malaysians. These experiences may have rendered ethnic tensions less visible, as many Chinese are less affected by them. Indeed, the comment above was made in a discussion at the Malaysian campus of an Australian university, as opposed to a Malaysian public university.

Another eight comments expressed the social and economic value of learning other heritage languages of Malaysia whereby the students reflected on the benefits, 
and their experiences, of individual multilingualism. Just as the Malays had argued, Chinese students explained they are advantaged by their quadrilingualism in a local Chinese heritage language, Mandarin as their community's lingua franca, Malay as the national language, and English. They described this as expanding their networks. For example:

(8)

Student 2:

Student 3:

Student 2:

Student 5:
Like, we can communicate with more people. It's a wider range of network then. If you are monolingual you can only speak...like if I only know English...I can only speak to...

A person who knows English.

Yeah.

You will become very quiet in Malaysia.

Others referred more specifically to the socioeconomic mobility of multilingual Chinese individuals, especially their ability to engage international markets and travel abroad. They explained that "we can go into any market: Indonesian market, Chinese market, even the Australian market, British market, American market", "like when we go to Hong Kong, we know how to speak Cantonese", and "it wouldn't benefit us if we didn't learn another language, then we can't communicate with outsiders". They therefore perceived socioeconomic advantages to all their languages.

More commonly, amounting to 15 comments across all the groups, the Chinese offered the principled argument that societal multilingualism maintains ethnic identities, and that Malaysia's constitutional arrangements that allow for cultural diversity should be respected. On the one hand, they implicitly criticised Malay nationalism by arguing that societal multilingualism "is our right", that removing vernacular education "defeats the purpose of our multiracial country in the first place", and that Malaysia "is a culture whereby we come from different cultures and races". On the other hand, they implicitly criticised some fellow Chinese for not being invested in Chinese language maintenance. They explained, for example, that "we should not forget our origins", and

$\begin{array}{lc}\text { Student 5: } & \text { It's about identity. } \\ \text { Researcher: } & \text { Identity? Ok. } \\ \text { Student 5: } & \text { I mean, if I go out and } \\ & \text { tell people I don't } \\ & \text { know Mandarin, } \\ & \text { then... } \\ \text { Student 4: } & \text { People will say like } \\ & \text { 'oh you are Chinese } \\ & \text { but you don't know } \\ & \text { Mandarin!' } \\ \text { Student 5: } & \text { Yeah, like a banana. }\end{array}$

Banana is slang for ethnic Chinese who are not proficient in Chinese language and lean towards a western identity. The reference to banana is especially emblematic 
of local sociopolitical pressure to maintain a Chinese ethnic identity amidst Malay hegemony that suppresses its linguistic indexes and a history of Chinese political activism against ethnocracy. This no doubt backgrounds emphatic Chinese support for societal multilingualism. In as far as banana describes an individual as "yellow on the outside, white on the inside" (Khor 2016), this reference asserts the normativity of any shift from Mandarin that does occur typically being to English, rather than to Malay. The remaining four responses caveated support for societal multilingualism. One explained that societal multilingualism is ideal but difficult in practice due to communication breakdowns between ethnic groups, and another argued that societal multilingualism should more consciously include Malaysia's small indigenous languages. The remainder argued that either English or a Chinese language should be hierarchised above Malay because many Malaysians are not proficient in Malay. These comments, and indeed Chinese discourses from the group discussions more broadly, were notably void of beliefs that the Malay language should, or necessarily does, lead Malaysia's societal multilingualism. For example, they explained that English is most important "because it's an international language", although it could be argued my presence as a native English speaker implicitly encouraged such a view. In another example, students in Penang took a localised view to argue that Hokkien is "most important" because "like the market, they mostly speak Hokkien lah. If you speak to them, some can speak Malay, but not all the hawkers know English".

When attributing mental states to their Malay and Indians peers, 18 of a total of 28 comments explained that ethnic Malays and Indians hold Mandarin in high regard, in turn meaning Chinese were self-assured in how others ideologically position their language. Ten comments explained that Malays and Indians recognise the economic value of Mandarin in advancing the economy and individual socioeconomic mobility. They especially reported that Chinese-medium education is therefore popular among non-Chinese families. For example, they argued that "their parents think that there is a need for their child to master this language not only as a Malaysian himself, but also for international purposes when you have to work with China in the future", "Malays, actually, they need Mandarin", and

Researcher:

Student 3:

Researcher:

Student 4:
I'm going to ask you, how do you think they feel about Mandarin?

As an opportunity because most businesses in Malaysia are, like, owned by Chinese, so if you know the Chinese language, you have, like, greater advantage.

Why do they learn Mandarin?

Because they are living in Malaysia.

Rather than attributing resistance to Mandarin, these students sooner believed that non-Chinese Malaysians see Mandarin as a necessary economic tool within Malaysia and that this ought to be reflected in policy. A presupposition, then, is that Chinese-Malaysians are not only unlikely to use Malay at work and that Chinese businesses seek Mandarin speakers, but that Malays and Indians accept that Mandarin holds greater currency than Malay. Accordingly, another three comments added 
that the non-Chinese enjoy learning Mandarin and it is "getting popular". Another three added that Malays and Indians support Mandarin because they want to "show respect to our culture" and that contemporary Malays are becoming more "open" to societal multilingualism than current policy.

Ten comments attributed negative affect. In particular, five upheld the belief that Malays do indeed see Mandarin as pivotal to the Malaysian economy, but are frustrated by this. They explained that Malays disrespect Mandarin - and ChineseMalaysians generally-because the relative socioeconomic disadvantage of the Malays means Malays have an "inferiority complex". They also explained that Malays and Indians find the frequent use of Mandarin in the economy "irritating". Another three comments added that Malays cannot accept multilingualism because they are hegemonic about Tanah Melayu and, as such, "they think in Malaysia you must speak Malay". This contrasts with the expressed attitudes of Malays which were more positive about societal multilingualism, albeit led by the Malay language. These negative attributions by the Chinese students may be sooner explained by Chinese metadiscourse about Malay nationalism than by direct conversations between these Chinese and Malay youths. The remainder simply argued that Chinese, Malays and Indians all historically dislike each other, and attributed this dislike to the perpetual stereotyping — no doubt passed down the generations- that "if you don't cheat, you are not Chinese. If you don't drink, you're not Indian. If you are hardworking, you are not Malay".

\section{Indian discussions}

This section shows that Indian students, albeit they formed a much smaller cohort mirroring their much smaller population size in Malaysia, were very enthusiastic about the perceived benefits of multilingualism. In particular, they commented in hypothetical terms that multilingualism would maintain ethnic identities and diversity and could achieve equality amongst Malaysians. Speaking about potential rather than actual benefits reflected Indian disappointment with hegemonic Malay policy and its limitations on egalitarian plurality. However, the students especially reflected in metalinguistic terms on the adverse impacts of ideology within the Indian community that neglects its own heritage languages. This section also shows that although the Malays and Chinese were enthusiastic about the representation of Indian languages in Malaysia's multilingualism, Indian students believed that their languages are either absent from Malay and Chinese metalinguistic awareness or are deemed to hold little value to Malaysia.

All nine attitudinal comments expressed support for societal multilingualism. Most of these equated language and linguistic diversity with ethnicity and ethnic diversity. This led to three comments that societal multilingualism has the potential to maintain ethnic identities and practices, and therefore maintain diversity in Malaysian society, and to achieve intercultural awareness between ethnic groups. They especially posited that within a truly multilingual society you "get to practice your own belief, your own language. This all preserves identity". The core concern 
for these students, however, was that their own community is complicit in jeopardising Malaysia's linguistic diversity because many Indian families have favoured English and have shifted to it as a language of prestige. From their perspective, their own community is displacing the cultural and economic advantages of societal multilingualism, and they wished to see this process reversed. They explained, for example, that "I mean you are born as a Tamil, so why are you not raised in a Tamil way? You know like, for me...I don't really speak Tamil", and

Student 2:

Student 4:

Student 3:

Student 5:

\author{
Maybe the Indians all go to Chinese schools or \\ Malays schools. They don't want to go to Tamil \\ schools. \\ The Indians themselves do not support... \\ Tamil schools. \\ Even the number of Tamil schools is decreasing.
}

Another two comments added that if intracommunity ideologies improved amongst Indians, then societal multilingualism would lead to widespread individual multilingualism across all Malaysia's ethnicities, and this would create equality between the ethnic groups. They questioned, for example, "if you speak English, you speak Malay, Chinese, why don't you speak Tamil?" and suggested that ideal multilingualism would mean that "everybody speaks four languages. That'd be great". The remaining comments in support of multilingualism argued, like the Chinese and the Malays, that individual multilingualism is socioeconomically enfranchising and therefore an aspiration for many individuals. They explained that "learning more and more languages is actually good lah" and "picking up Mandarin would be good" in order to be "well-equipped the moment you go to the outside world".

Although the Malays and Chinese were generally enthusiastic about societal multilingualism fostering ethnic diversity and language maintenance, the Indian students did not attribute them with a corresponding mental state. Instead, three asserted that Indian languages are absent from the metalinguistic consciousness of Malays and Chinese, noting "my friends actually don't know anything about it [Tamil]", "they don't think about it", and "they don't give Tamil much thought". This attribution is contextualised by a further six comments that lamented Malays and Chinese affording little instrumental value to Indian languages. However, rather than blaming the Malays and Chinese, the Indian students again blamed their community and saw this attitude as originating in an Indian ideology that pedestalises English. That is to say, the students argued that the Malays and Chinese can be forgiven for devaluing Tamil, given the Indian community itself devalues it. For example, they explained "I have come across one person that asked me 'if you talk in Tamil, what do you gain from that? You gain nothing. If you talk in English, then you can do business. If you learn Mandarin, then you can do business. If you learn Tamil, you can't do anything", "people are not putting Tamil as important as other languages. That's the thing", and 
(13) Student 1: [Malays and Chinese] should start changing the way they think about Tamil, that it is low, that just because you speak Tamil you are a disgrace or something. Because a lot of people have that mentality.

Researcher: They do?

Student 2: They do.

Student 1: They do, yeah.

Student 2: Even...

Student 3: In the Indian community.

Student 1: Even Indians.

Student 2: They are sending their children to, you know, Malay schools, Chinese schools. Or, I want my children to learn another language but not their own mother tongue.

Student 1: Because they themselves are stepping down on it, you know.

Student 2: So, they should change.

Student 1: Yeah, change the mind-set. Tamil is not going to bring you down.

Student 2: It happens with the mothers you know. Like, the mothers when they meet up, right, they will be like 'oh, you send your daughter to Tamil school, really? Why didn't you enrol in the national school or some English school?'

The remaining eight comments attributed neutral or positive mental states to ethnic Malays and Chinese. However, they mostly hypothesised feelings about societal multilingualism rather than about Indian languages specifically. They argued that "I don't think [multilingualism] is an issue for them because it has pretty much been like this, three difference races, for a very, very long time". Accordingly, another two comments suggested that community attitudes to societal multilingualism are generally favourable, even among Malays, and "it is just politicians making this an issue". Five comments even explained that the Malays and Chinese indeed respect Indian identities and are enthusiastic about diversity. In one case, a student explained "even a close friend, he is Chinese. He comes and asks me 'why do you Indians not like to communicate in Tamil? Why do you all use English?' I felt very bad that he asked me that". Others explained that "they are actually showing some interest. Not that your language is what you speak, and my language is what I speak. That it's our language. That's for all of us to learn". That is to say, Indian students tended to either feel that Malays and Chinese were positive towards multilingualism in general or specifically negative towards Tamil, rather than necessarily positive towards Tamil.

\section{Conclusions}

Borrowing perspectives from theory of mind to research language beliefs has allowed for a more dynamic case study of social psychology vis-à-vis societal multilingualism than unidirectional attitudinal research can achieve. Understanding how people in linguistically diverse societies feel about societal multilingualism, as a pillar of language policy, can of course be pursued through traditional attitude research methodologies. To this end, and by taking a direct qualitative approach, the article has shown that a cohort of tertiary educated Malay youth was more enthusiastic about societal multilingualism than Malaysia's ethnonationalist language policy 
supporters might appreciate. They, along with their ethnic Chinese and Indian peers, were positive about the cultural and economic benefits of societal and individual multilingualism. Nonetheless, Malay students wanted to retain a linguistic hierarchy, Chinese students reasserted multilingualism as an ethnic right to be reflected in policy, and Indian students positioned the benefits of societal multilingualism as aspirations rather than reality.

However, this paper has also shown that, where societal multilingualism is fraught with interethnic tensions and a complex sociopolitical history, how people think they are perceived by others is as research-worthy as how they themselves perceive those around them. This helps to gauge the state of ethnolinguistic relations and pursue what scholarship has coined ideological clarification in the context of language policy change and discourse. On this note, this article has revealed alignments and chasms between the attitudes expressed by Malaysians of different ethnic groups vis-à-vis multilingualism, and the mental states others attributed to those ethnicities. For example, Chinese students correctly hypothesised that Malays see Mandarin as advancing Malay socioeconomic opportunity, but did so with the presupposition that ethnic Malays have accepted Mandarin to be a language that they ought to acquire for socioeconomic mobility, regardless of current language policy. This contrasted with Malay attitudes which generally recognised the socioeconomic instrumentality of Mandarin and the need to learn it, but reasserted that this should not be at the expense of Malay as the national language. Some Malay youths correctly hypothesised that the Chinese and Indians often reject the elevated status of Malay. Whereas Malay students attributed this to non-Malays disrespecting Tanah Melayu, the Chinese and Indian students saw Malay ideology as hegemonic, and therefore encouraged Malays to become open-minded. Other Malay students explained that Chinese and Indian Malaysians are satisfied with their pendatang status, are eager to engage ethnic Malays, and therefore endorse the supremacy and national status of the Malay language. This, however, was not paralleled in Indian and Chinese discourses that sooner afforded prestige to English or Mandarin, or that sought equality between the ethnicities. Whereas the Indian students argued that their languages are largely absent from Chinese and Malay metalinguistic awareness and ignored by policy, the Chinese and Malay students were supportive of Indian language maintenance as an expression of Indian culture and identity.

Time will tell whether Malaysia's new political environment will realign language policy such that it appeases the perspectives offered by these youths. In any case, researching beliefs multidirectionally can create a more robust and dynamic understanding of grassroots sociolinguistic perspectives within a language polity as they are reported and indeed experienced on the ground. My view is that this multidirectionality can be of practical value to social policy makers and advocates. In as far as beliefs drive language policy and impact its reception, then multidirectional social psychological research better places us to survey relative ideological positioning, to identify disputes and misconceptions between groups that can be addressed in the policy-making process, and to forecast the likely success of policy ideas. This was especially pronounced, for example, in the case of Indian youths who hypothesised a much lower ideological position for themselves than that constructed for them by Malay and Chinese students. This suggests that the non-Indian peers of 
these Indian students are more enthusiastic about Indian languages than these Indian students realised. Identifying and clarifying chasms such as these can only benefit language policy discourses. On the other hand, Malay students were arguably more enthusiastic about diversity than many non-Malays may believe, but still preferred a Malay-led hierarchy. Non-Malays predicted the latter, and wanted to see their language rights elevated, suggesting that even amongst Malaysia's educated youth there remains an ideological challenge to achieving linguistic equality. In any case, Malaysia shows us that vantage points vis-à-vis societal multilingualism are nuanced not only by one's own dispositions, but also by those assumed to be held by others.

Acknowledgements I would like to express my sincerest thanks to Professor Jacob Mey, Professor Louise Cummings, and Professor Bernadette Watson who encouraged this interdisciplinary paper. I would also like to thank the Malaysian youths who participated in this research for their enthusiasm and engagement.

Funding Funding was provided by H2020 Marie Skłodowska-Curie Actions (Grant No. 707404).

Open Access This article is licensed under a Creative Commons Attribution 4.0 International License, which permits use, sharing, adaptation, distribution and reproduction in any medium or format, as long as you give appropriate credit to the original author(s) and the source, provide a link to the Creative Commons licence, and indicate if changes were made. The images or other third party material in this article are included in the article's Creative Commons licence, unless indicated otherwise in a credit line to the material. If material is not included in the article's Creative Commons licence and your intended use is not permitted by statutory regulation or exceeds the permitted use, you will need to obtain permission directly from the copyright holder. To view a copy of this licence, visit http://creativecommons.org/licen ses/by/4.0/.

\section{References}

Ahmad, R., \& Tan, T. (2018). Dr Mahathir defends Guan Eng's Mandarin press statement. Retrieved June 3, 2019, from https://www.thestar.com.my/news/nation/2018/06/25/dr-mahathir-defends-guanengs-mandarin-press-statement/.

Albury, N. J. (2017). Mother tongues and languaging in Malaysia: Critical linguistics under critical examination. Language in Society, 46(4), 567-589. https://doi.org/10.1017/S0047404517000239.

Ames, D. R. (2004). Inside the mind reader's tool kit: projection and stereotyping in mental state inference. Journal of Personality and Social Psychology, 87(3), 340.

Andaya, B. W., \& Andaya, L. Y. (2016). A history of Malaysia. London: Palgrave Macmillan.

Barr, M. D., \& Govindasamy, A. R. (2010). The Islamisation of Malaysia: Religious nationalism in the service of ethnonationalism. Australian Journal of International Affairs, 64(3), 293-311.

Berry, J. W., Phinney, J. S., Sam, D. L., \& Vedder, P. (2006). Immigrant youth: Acculturation, identity, and adaptation. Applied Psychology, 55(3), 303-332.

Coluzzi, P. (2017). Language planning for Malay in Malaysia: A case of failure or success? International Journal of the Sociology of Language, 2017(244), 17-38. https://doi.org/10.1515/ijs1-2016-0055.

Dauenhauer, L. M., \& Dauenhauer, R. (1998). Technical, emotional and ideological issues in reversing language shift: Examples from Southeast Alaska. In L. A. Grenoble \& L. J. Whaley (Eds.), Endangered languages: Language loss and community response (pp. 57-98). Cambridge: Cambridge University Press.

David, M. K. (2017). Reasons for language shift in Peninsular Malaysia. Journal of Modern Languages, 15(1), 1-11.

Department of Statistics Malaysia. (2015). Population and demography. Retrieved June 3, 2016 from https://www.statistics.gov.my/index.php?r=column/ctwoByCat\&parent_id=115\&menu_id=L0phe U43NWJwRWVSZklWdzQ4TlhUUT09.

Eagly, A. H., \& Chaiken, S. (1993). The psychology of attitudes. Fort Worth, TX: Harcourt Brace Jovanovich College Publishers. 
Erni, J. N., \& Leung, L. Y.-M. (2014). Understanding South Asian minorities in Hong Kong. Hong Kong: Hong Kong University Press.

Fauzi Abdul Hamid, A. (2007). Malay anti-colonialism in British Malaya: A re-appraisal of Independence Fighters of Peninsular Malaysia. Journal of Asian and African Studies, 42(5), 371-398.

Fishman, J. (1990). What is reversing language shift (RLS) and how can it succeed? Journal of Multilingual and Multicultural Development, $11(1 \& 2), 5-36$.

Gal, S. (2006). Migration, minorities and multilingualism: Language ideologies in Europe. In C. MarMolinero \& P. Stevenson (Eds.), Language ideologies, policies and practices (pp. 13-27). London: Palgrave Macmillan.

Gill, S. K. (2013). Language policy challenges in multi-ethnic Malaysia (Vol. 8, Multilingual Education). Dordrecht: Springer

Jaffe, A. (2009). Introduction: The sociolinguistics of stance. In A. Jaffe (Ed.), Stance: Sociolinguistic perspectives (pp. 3-28). New York: Oxford University Press.

Khor, S. (2016). 10 annoying things 'bananas' have to put up with because they're "not Chinese enough". Retrieved June 15, 2018, from https://says.com/my/fun/how-to-crush-a-chinese-banan as-soul.

King, K. (2000). Language ideologies and heritage language education. International Journal of Bilingual Education and Bilingualism, 3(3), 167-184.

Kusow, A. M. (2003). Beyond indigenous authenticity: Reflections on the insider/outsider debate in immigration research. Symbolic Interaction, 26(4), 591-599.

Lewis, G. E. (1981). Bilingualism and bilingual education. Oxford: Pergamon Press.

Li, J., \& Marshall, S. (2018). Engaging with linguistic landscaping in Vancouver's Chinatown: A pedagogical tool for teaching and learning about multilingualism. International Journal of Bilingual Education and Bilingualism. https://doi.org/10.1080/13670050.2017.142247.

Liu, J. H., Lawrence, B., Ward, C., \& Abraham, S. (2002). Social representations of history in Malaysia and Singapore: On the relationship between national and ethnic identity. Asian Journal of Social Psychology, 5(1), 3-20. https://doi.org/10.1111/1467-839X.00091.

Mahathir, M. (1970). The Malay dilemma. Singapore: Asia Pacific Press.

Mahboob, A., \& Jain, R. (2016). Bilingual education in Pakistan and India. In O. Garcia, A. M. Y. Lin, S. May \& N. Hornberger (Eds.), Bilingual and multilingual education (3rd ed., pp. 233-246). Cham: Springer.

May, S., \& Sleeter, C. E. (2010). Critical multiculturalism: Theory and praxis. New York: Routledge.

Mukherjee, H., Singh, J. S., Fernandez-Chung, R. M., \& Marimuthu, T. (2017). Access and equity issues in Malaysian higher education. In S. Malakolunthu \& N. C. Rengasamy (Eds.), Policy discourses in Malaysian education: A nation in the making. London, New York: Routledge.

Noor, N. M., \& Leong, C.-H. (2013). Multiculturalism in Malaysia and Singapore: Contesting models. International Journal of Intercultural Relations, 37(6), 714-726.

Schiffman, H. (2006). Language policy and linguistic culture. In T. Ricento (Ed.), An introduction to language policy: Theory and method (pp. 111-125). Malden: Blackwell.

Sodian, B., \& Kristen, S. (2010). Theory of mind. In B. Glatzeder, V. Goel, \& A. Müller (Eds.), Towards a theory of thinking: Building blocks for a conceptual framework (pp. 189-201). Berlin, Heidelberg: Springer.

Spolsky, B. (2004). Language policy. Cambridge: Cambridge University Press.

Tan, R. (2008). Taking politics out of education. Retrieved October 4, 2017 from http://www.malaysianb ar.org.my/members_opinions_and_comments/roger_tan_taking_politics_out_of_education.html.

Tho, X. Y., \& Tan, V. (2019). Malaysia's Chinese independent schools face uphill climb in quest for qualification recognition. Retrieved June 15, 2018, from https://www.channelnewsasia.com/news/ asia/malaysia-chinese-independent-schools-uec-recognition-11476890.

van Dijk, T. A. (2003). The discourse-knowledge interface. In G. Weiss \& R. Wodak (Eds.), Critical discourse analysis: Theory and interdisciplinarity (pp. 85-109). London: Palgrave Macmillan UK.

Wigboldus, D. H. J., \& Douglas, K. (2007). Language, stereotypes, and intergroup relation. In K. Fiedler (Ed.), Social communication (pp. 79-106). New York, Hove: Psychology Press.

Wodak, R., \& Meyer, M. (2009). Methods for critical discourse analysis. London: Sage.

Publisher's Note Springer Nature remains neutral with regard to jurisdictional claims in published maps and institutional affiliations. 
Nathan John Albury holds a PhD in sociolinguistics from the University of Oslo. His research focuses on mutlilingualism, ethnic relations, and language policy and ideology. He is currently a policy adviser at Leiden University in the Netherlands. 